\title{
By-Products in the Malting and Brewing Industries-Re-Usage Possibilities
}

\author{
Andrea Karlović ${ }^{1}$, Anita Jurić ${ }^{1}$, Nevena Ćorić ${ }^{1}$, Kristina Habschied ${ }^{2, *}$, Vinko Krstanović ${ }^{2}$ (D) \\ and Krešimir Mastanjević 2 (D) \\ 1 Faculty of Agronomy and Food Technology, University of Mostar, 88000 Mostar, Bosnia and Herzegovina; \\ andrea.karlovic@aptf.sum.ba (A.K.); anita.juric@aptf.sum.ba (A.J.); nevena.coric@aptf.sum.ba (N.Ć.) \\ 2 Faculty of Food Technology, Josip Juraj Strossmayer University of Osijek, 31000 Osijek, Croatia; \\ vkrstano@ptfos.hr (V.K.); kmastanj@gmail.com (K.M.) \\ * Correspondence: kristinahabschied@gmail.com; Tel.: +385-31-224-300
}

Received: 13 July 2020; Accepted: 6 August 2020; Published: 8 August 2020

\begin{abstract}
Beer production includes the formation of different by-products such as wastewater, spent grains, spent hops, and yeast. In addition to these well-known by-products, it is necessary to mention germ/rootlets, which also remain after the malting process. Given that a huge amount of beer is produced annually worldwide, by-products are available in large quantities throughout the year. Spent grains, spent hops, and spent yeasts are high-energy raw materials that possess a great potential for application in the branch of biotechnology, and the food industry, but these by-products are commonly used as livestock feed, disposed of in the fields, or incinerated. Breweries by-products can be utilized for microalgae production, biofuel production, extraction of proteins, polyphenolic, antioxidative substances, etc. This paper aims to address each of these by-products with an emphasis on their possible application in biotechnology and other industries.
\end{abstract}

Keywords: by-products; malting; brewing; reuse

\section{Introduction}

Beer is an alcoholic beverage derived from malted cereals, water, yeast, and hops, left to ferment for a certain period of time, (usually two to three weeks). Over the years, beer has become an important nutritive beverage for a wide population of people [1]. Due to the availability of cereals needed for its production, it was brewed all over the world. Production technology became more sophisticated, new flavors were introduced, and the old ones were improved. Today, beer is one of the most favorite beverages in the world. In 2015, according to the internet source [2], it was predicted that the brewing industry, will be worth around 700 billion USD, by the year 2020. As mentioned in the abstract, malting and brewing industries produce different by-products (water, spent grains, spent hops and yeast, and germ/rootlets). Considering the vast industrial production of malt and beer, by-products are available in large quantities throughout the year and can be utilized in different ways. Spent grains (38.6 $\times 10^{6} \mathrm{t}$ worldwide) [3] and spent yeasts (125,000 tons/y in Europe) [4] are high-energy, protein-rich raw materials and can be used as livestock feed. However, some of these by-products also possess great potential for application in the biotechnology field. Therefore, this review will address each of these by-products, and explain the possible application in biotechnology and other industries.

Beer can be produced from different cereals, but in most countries, the major malting commodity is barley. The addition of different adjuncts (unmalted barley, unmalted wheat, corn grits, rice, glucose syrup, etc.) can greatly aid the financial aspect of beer production. The fermentation process includes the production of two major products: ethanol and $\mathrm{CO}_{2}$. Other chemical compounds that are immensely important constituents of beer aroma and taste are also a result of alcoholic fermentation. 
At the end of the main fermentation, the obtained young/green beer usually has an unpleasant taste and smells of yeast. It has a low content of $\mathrm{CO}_{2}$ and high turbidity due to suspended particles. Secondary fermentation which entails maturation of green beer adds specific value, in terms of aroma formation, to the final product.

\section{Basic Production Technology of Beer}

Barley or other cereals traditionally used in the production of beer do not have active amylolytic enzymes that are significant for the process of fermentation. To activate the enzymes, it is necessary to conduct the malting of cereals, and ensure that there are satisfactory levels of reducible sugars for yeast. Malting can be described as a simulation of germination under controlled conditions. By setting process conditions, physiological and biochemical reactions in the grain are set to ensure the partial modification of grains to obtain the malt. The malting process subjects the grain to three basic phases [1]:

1. Water absorption (swelling);

2. Germination;

3. Kilning;

4. Stabilization of malted grain.

Malt prepared in this way is then subjected to different unit operations which result in the production of wort, and after fermentation, beer.

Beer is a nutritious product, a result of the alcoholic fermentation of the wort. According to Bavarian Purity Law (Reinheitgebot from the year 1516), four basic raw materials are used for beer production: water, hops, barley, and brewer's yeast. Beer produced in discordance with the Bavarian Purity Law can contain different unmalted adjuncts (semolina, oats, wheat, rice, etc.) or other malted cereals (wheat, sorghum, millet, etc.) [1]. Beer production involves a series of unit operations that can be summarized into several stages:

1. Malt production;

2. Wort production;

3. Main fermentation;

4. Secondary fermentation-maturation of young beer;

5. Finishing;

6. Packaging of beer.

The production of wort results in the addition of hop. After cooling, yeast is added, and the main fermentation begins. As mentioned before, the young beer is unpleasant in taste and smell, but the secondary fermentation enriches the aroma and taste profile of beer with the formation of different volatile compounds (acetaldehyde, dimethyl sulfite, ethyl acetate, isoamyl acetate, propanol, isobutanol, isoamyl alcohol, diacetyl, higher alcohols, esters, and pentanedione) important for consumers' acceptance [5].

\section{Malting and Brewing By-Products}

Malting and brewing lead to a huge amount of various by-products. The majority of these by-products are commonly utilized as fertilizers in the field, get incinerated, or drained in sewage as waste. This kind of use of the by-product spells a major environmental problem and needs to be addressed since the development of new technologies can influence and redirect the misuse of such biotechnologically important by-products. The reduction of by-products to a minimum, or re-incorporation into the production process as raw materials can help achieve ecological sustainability. Considering that some of the by-products originating from the malting and brewing industries are nutritious and valuable, but cheap and affordable, they can be incorporated into various industries oriented towards food, pharmaceuticals, or biotechnology production. 
The beer production process consists of a series of unit operations. Considering that the ratio between the spent water and produced beer is 1:10 L of water [6], it is not surprising that water is the most abundant by-product in the brewing industry. In addition to water, by-products of the brewing industry are spent grain, spent brewer's yeast, and spent hops/hot trub. Malting production also utilizes a lot of water and results in germ/rootlets after the de-germination of finished malt.

Regardless of the by-product in question, it is necessary to find new ways of using them, safely dispose of them in nature, or reduce their occurrence.

\subsection{Water}

Production of $1 \mathrm{~L}$ of beer consumes $10 \mathrm{~L}$ of water [6] and about $7 \mathrm{~L}$ ends up as wastewater [7]. The amount of used water may go below the mentioned values in larger breweries [1] or if advanced technology is used (2.2-3.3 hL of water for $1 \mathrm{hL}$ of beer), but the disposal of brewery wastewater is still a great challenge. The largest amount of water used in breweries is used for cleaning and disinfection in the brewing industry (48\%) [8].

Water is present through all stages of the production process [9], so it is not surprising that wastewater differs in composition, as shown in Table 1. Apart from the shown components, it can contain residues of the cleaning agents (wastewater from CIP (cleaning in place) system, waste alkalis from the CIP system, acids from the CIP system), as well as residues from basic raw materials and other chemicals used in beer production (beer, wort, spent grain, hops, yeast, alkalis from the polyvinylpolypyrrolidone (PVPP) filter, diatomaceous earth, etc.) [1]. Brewery wastewater usually contains sugars, soluble starches, ethanol, volatile fatty acids, and suspended solids [6].

Table 1. Chemical composition of wastewater from breweries according to different sources.

\begin{tabular}{|c|c|c|}
\hline Parameters & Values & Source \\
\hline \multirow{2}{*}{$\mathrm{pH}$} & $3-12$ & \multirow{21}{*}[10-13]{} \\
\hline & $4-1$ & \\
\hline \multirow{3}{*}{ Temperature } & $18-40^{\circ} \mathrm{C}$ & \\
\hline & $10-20$ & \\
\hline & $24-30$ & \\
\hline \multirow{2}{*}{ Chemical oxygen demand (COD) } & $2000-6000 \mathrm{mg} / \mathrm{L}$ & \\
\hline & $1000-6000 \mathrm{mg} / \mathrm{L}$ & \\
\hline \multirow{3}{*}{ Biological oxygen demand $\left(\mathrm{BOD}_{5}\right)$} & $1200-3600 \mathrm{mg} / \mathrm{L}$ & \\
\hline & $0.44-0.95$ g/g d.m. & \\
\hline & $1600-4000 \mathrm{mg} / \mathrm{L}$ & \\
\hline \multirow{2}{*}{ Volatile fatty acids } & $1000-2500 \mathrm{mg} / \mathrm{L}$ & \\
\hline & $350 \mathrm{mg} / \mathrm{L}$ as acetic acid & \\
\hline \multirow{2}{*}{ Phosphates as $\mathrm{PO}_{4}$} & $10-50 \mathrm{mg} / \mathrm{L}$ & \\
\hline & $2-43 \mathrm{mg} / \mathrm{L}$ & \\
\hline \multirow{2}{*}{ Total nitrogen per Kjeldahl } & $25-80 \mathrm{mg} / \mathrm{L}$ & \\
\hline & $16-67 \mathrm{mg} / \mathrm{L}$ & \\
\hline Total solids & $5100-8750 \mathrm{mg} / \mathrm{L}$ & \\
\hline \multirow{2}{*}{ Total suspended solids } & $2901-3000 \mathrm{mg} / \mathrm{L}$ & \\
\hline & 187-2000 mg/L & \\
\hline Total dissolved solids & $2020-5940 \mathrm{mg} / \mathrm{L}$ & \\
\hline Total dry matter & 1900-8000 mg d.m./L & \\
\hline
\end{tabular}


Huge amounts of water after the beer production process demand appropriate environmental-friendly solutions for pollution reduction. Strict laws that require proper disposal of wastewater from the brewery, and high fees for the release of wastewater into the sewer without prior treatment, have forced the brewing industry to find new ways to use wastewater. To address this issue, the following measures can be applied:

1. Reduction of water usage in the production process, or the introduction of new technologies;

2. Redirecting the used water in further activities;

3. Proper treatment before being released into the wastewater system or the environment [7].

To reduce water consumption, the European IPPC (Integrated Pollution Prevention and Control) Institute gave several guidance points for the brewing industries [14]:

1. Reuse of hot water obtained by cooling wort-hot water is stored in thermally insulated containers and can be used for various purposes (for cleaning, rinsing, or heating rooms);

2. Reuse of wastewater from the strainer;

3. Reuse of water used for bottling in pasteurization;

4. Use of cross-flow filtration.

However, some breweries cannot afford the introduction of such expensive technologies, so some alternatives for the utilization of brewery wastewater have been proposed. For example, since this water is rich in carbon and other nutrients needed for growth and development of microalgae, it is possible to use wastewater from the brewery in the process of microalgae production $[7,15]$. Growing of microalgae, to produce biogas, is still in its infancy, Maintinguer et al. [16] have managed to isolate Enterobacter strains from the brewery wastewater to produce hydrogen that can be used as a source of energy.

Brewery wastewater contains high concentrations of organic matter, which is why it can act as a good nutrient medium in hydroponic plant cultivation [17]. This involves plant cultivation with the use of water and minerals, but without soil [18]. However, if wastewater from the brewery is to be used in this type of cultivation, anaerobic pre-treatment should be conducted [7].

During beer filtration, a certain amount of polyphenols ends up in brewery wastewater [19]. Therefore, Barbosa-Pereira et al. [20] claim that there is a great potential for the application of wastewater from this process as a raw material for the production of polyphenols or antioxidants. Wastewater can also be used to produce biogas rich in methane $\left(\mathrm{CH}_{4}\right)$ and hydrogen $\left(\mathrm{H}_{2}\right)$. Anaerobic digestion is cited as one of the methods of obtaining biogas [21]. Research has also been done on obtaining biohydrogen from wastewater using a culture produced by natural fermentation of synthetic wastewater, and Klebsiella pneumoniae isolated from the environment [22].

Wastewater, both from other industries and the brewery, is subject to pre-treatment to prevent and limit the negative impact on the environment. Wastewater treatment in the brewery is divided into primary and secondary treatment, which means changing the physical, chemical, and/or biological properties of wastewater to achieve better effects of subsequent processes [6]. Physical methods are the primary methods by which solids found in water such as label paper, sludge, and large particles are removed [1]. Such methods are among the simplest and most economical, which is why most breweries can afford them, but it should be emphasized that physical methods do not remove the solutes that affect the ecosystem negatively [23]. The physical methods used are sieving, comminution, flow equalization, sedimentation, flotation, and filtration through a granular medium [6]. Given that $48 \%$ of the total amount of water in brewing is used for cleaning and disinfection, it is not surprising that wastewater contains various chemical compounds. For these chemical compounds to be safely removed, chemical methods that involve different chemical reactions are used. Methods of coagulation, flocculation, and $\mathrm{pH}$ adjustment are used to remove toxic strains and colloidal impurities [24]. Just like physical, chemical methods are easy to use, but considerably more expensive making them unattainable for smaller breweries [25]. Chemical precipitation, adsorption, disinfection, chlorination, and other 
chemical processes are commonly used to purify water [6]. Biological methods are used to reduce the concentration or remove organic, and inorganic compounds [25] and we divide them into anaerobic, aerobic, and anoxic [7]. Biological processes involve the application of microorganisms in biodegradable pollutants in wastewater through the processes of removal of carbon organic matter, nitrification, denitrification, and stabilization [25]. During anaerobic and aerobic processes, methane is formed, which can be used as a propellant [7]. However, it should be considered that the use of detergents containing fatty acid esters can significantly reduce methane production ( $35 \%$ less) and influence the course and effectiveness of the process [26]. These processes are mainly done in large breweries, due to the high cost of energy that they consume [27]. The biological method of wastewater treatment is by far the best, because, there is a high degree of reduction of COD (chemical oxygen demand) and BOD (biological oxygen demand) (80-90\%) [25]. Some of these procedures involve activated sludge processes, aerated lagoons, drip filters, biological contactors, stabilization pools, anaerobic systems, biological removal of substances [6]. Although the biological method of processing is the best in relation to physical and chemical methods, it should be emphasized that it belongs to the secondary form of purification and should always be preceded by primary methods (physical and chemical). The best form of wastewater treatment is a combination of the mentioned methods.

Recently, extensive research has been invested in wastewater treatment by microfiltration, ultrafiltration, nanofiltration, and reverse osmosis (hyperfiltration) [28]. Due to the excellent ability to separate solid solutes from solvents, low energy consumption, high flow, good chemical resistance, and low cost of membrane materials [29], it is not surprising that this technology has found new applications in the food industry. In brewing, membrane technology is primarily used for the filtration of beer [30]. However, Braeken et al. [31] investigated the effectiveness of nanofiltration in the treatment of wastewater left behind after the beer production process. Although nanofiltration is used to obtain drinking water, removing low molecular weight organic compounds $(200 \mathrm{~g} / \mathrm{mol})$ and additives found in detergents, this study did not find it sufficiently efficient for wastewater treatment. High ethanol concentrations harmed nanofilters [31]. In a study conducted by Gotz et al. [32], it was found that alkalis used for regeneration (PVPP), for cleaning, for washing bottles, and lubricating conveyor belts negatively affected filtration in low-pressure membranes. Therefore, these alkalis should be removed before the filtration process by physical and chemical methods [32]. Both of these studies show that membrane technology in brewing is effective only if used with other methods that will prevent the negative effects of certain compounds on membranes. A membrane bioreactor (MBA) [33] was developed in the 1960s. It is a combination of several methods and processes in one device (grids, sand traps, fine sieves, aerobic/anaerobic bioreactor, and membrane filters) [34]. This bioreactor has also been used in the brewing industry, and the best form of wastewater treatment from the brewery has been the anaerobic bioreactor (AnMBA) with a fluidized bed where the efficiency of organic matter removal resulted in a reduction in COD of more than 90\% [7,35]. Chen et al. [36] achieved a COD reduction of up to $98 \%$ with a production of $0.53 \mathrm{~L}$ of biogas/g KPC $\left(35^{\circ} \mathrm{C}\right)$.

Scientists are finding new ways to achieve energy-efficient processes [37]. One of the attempts is the application of electrochemical methods in the treatment of wastewater coming from the brewery. These methods are based on the principle of obtaining energy from organic compounds found in wastewater. Namely, the removal of organic compounds [27], as the major oxidizing substances that will use up the oxygen needed for aquatic life in rivers and seas. Scientist Wang et al. [37] published a paper based on research on the efficiency of a microbial chemical reactor with continuous mixing (CSMER) on the treatment of complex organic compounds, comparing this technique with a continuous mixing reactor (CSTR) and other systems that focus on microbial chemical (MESs) processes and the traditional anaerobic process.

Some smaller breweries, discharge wastewater into the sewage system without prior treatment, which significantly affects the ecosystem. Oxygen is used for the decomposition of waste substances, which is why some living organisms die due to a lack of oxygen. Also, a large amount of suspended solids reduces the amount of light, which can be detrimental to photosynthetic organisms [7]. 


\subsection{Spent Grains}

Spent grain is the most important by-product of the brewing industry [38]. This represents insoluble components left after lautering, just before fermentation [1]. The chemical composition of spent grain can vary, depending on the quality of barley or other cereals used in beer production, but it can also depend on other factors such as harvesting time, malting germination conditions, and the quality of unsweetened raw materials. Spent grain is a (Table 2) lignocellulosic material rich in proteins, fibers (20-70\%), minerals, and vitamins [39].

The spent grain contains a large proportion of moisture because it separates after mashing [1]. The moisture of the spent grain ranges between $75-80 \%$. Considering that beer is produced and consumed throughout the year, it is understandable that large quantities of spent grain are formed, which, if not properly disposed of, can be a major environmental problem, just like wastewater from the brewery. The Environmental Protection Agency states that nearly 34-35 million tons of spent grains are produced annually in Europe $[40,41]$. Since trub contains such a large share of water, it is prone to microbiological spoilage. To preserve the quality of the spent grain, but also to extend its shelf life, it is necessary to remove the water content by applying the drying process. Dried spent grains should contain no more than $10 \%$ water. Drying not only prevents spoilage but also reduces the volume of the spent grain, which facilitates storage and transport [42]. In addition to drying, trub can be preserved for three months by the addition of lactic acid, potassium sorbate, or one of the listed acids (acetic, formic, or benzoic) [43,44]. Spent grain, due to its chemical composition, has a high energy value, which classifies it as a by-product of high biotechnological importance.

Table 2. Chemical composition of brewer's spent grain according to different sources.

\begin{tabular}{|c|c|c|c|}
\hline \multicolumn{2}{|c|}{ Component } & Value & Source \\
\hline \multicolumn{2}{|l|}{ Water } & $75-80 \%$ & \\
\hline \multicolumn{2}{|c|}{ Hemicellulose } & $20-25 \%$ & \\
\hline \multicolumn{2}{|l|}{ Proteins } & $19-30 \%$ & \\
\hline \multicolumn{2}{|l|}{ Cellulose } & $12-25 \%$ & [45-47] \\
\hline \multicolumn{2}{|l|}{ Lignin } & $12-28 \%$ & \\
\hline \multicolumn{2}{|l|}{ Lipids } & $10 \%$ & \\
\hline \multicolumn{2}{|l|}{ Ash } & $2-5 \%$ & \\
\hline \multirow{4}{*}{ Minerals } & Phosphorous & 2000 ppm & \multirow{4}{*}{ [48] } \\
\hline & Calcium & $1040 \mathrm{ppm}$ & \\
\hline & Magnesium & 690 ppm & \\
\hline & Silicon & $240 \mathrm{ppm}$ & \\
\hline \multirow{8}{*}{ Vitamins } & Choline & $1800 \mathrm{ppm}$ & \multirow{8}{*}[42,49]{} \\
\hline & Niacin & 44 ppm & \\
\hline & Pantothenic acid & $8.5 \mathrm{ppm}$ & \\
\hline & Riboflavin & $1.5 \mathrm{ppm}$ & \\
\hline & Thiamine & $0.7 \mathrm{ppm}$ & \\
\hline & Pyridoxine & $0.7 \mathrm{ppm}$ & \\
\hline & Folic acid & $0.2 \mathrm{ppm}$ & \\
\hline & Biotin & $0.1 \mathrm{ppm}$ & \\
\hline
\end{tabular}

Regardless of its biotechnological significance, spent grain has found greater application only as animal feed [50] and one of the reasons is the complex structure of lignin and crystallization of cellulose, which complicates enzymatic hydrolysis [51]. Due to the high content of protein, nitrogen 
compounds, and low price, spent grain is increasingly present in the diet of livestock. It can be sold to farmers in the wet state or delivered to producers of dried spent grain [3]. Regions that do not have a developed industry for breeding ruminants and other domestic animals, mainly deposit the spent grain in the fields [52]. However, in recent decades it has become a focus of various studies that have yielded good results for biofuel production, isolation and production of phenolic compounds, lactic acid, growth, and cultivation of microorganisms, fungi, enzymes, and many other applications [50]. In addition to the above, research has been conducted to improve the properties of the spent grain. In 2011, Chinese scientists Ding et al. [50] researched the impact of spent grain fermentation by efficient microorganisms on increasing total proteins. The study showed that under certain parameters, ( $\mathrm{pH} 4.0$, inoculation $3 \%, \mathrm{~T}-28{ }^{\circ} \mathrm{C}, \mathrm{t}-3 \mathrm{~d}$ ) the protein content reached $31.7 \%$. This percentage also was in favor of the nutritional value of spent grain in livestock nutrition. Other pretreatments such as sulfuric acid $\left(15 \% \mathrm{w} / \mathrm{w}\right.$ BSG, $\left.\mathrm{pH} 1.0,121^{\circ} \mathrm{C}\right)$ are mentioned in the literature [53]; phosphoric acid $\left(155{ }^{\circ} \mathrm{C}, 2.0 \%\right.$ $\mathrm{H}_{3} \mathrm{PO}_{4}$ ) [54]; fermentation with $S$. cerevisiae and A. oryzae [55]; Escherichia coli [51]. Instead of ending up as lignocellulosic waste, spent grain can be used to produce biofuels, which are a substitute for fossil fuels [56]. In addition to acid pretreatment, bioethanol production was performed by fermentation with the help of various microorganisms: Pichia stipitis and Kluyveromyces marxianus [57], Neurospora crassa and Fusarium oxysporum [58], and Scheffersomyces stipitis and E. coli [56]. González-García et al. [59] came to the conclusion that the production of biogas itself is not economically viable, and that, by creating a biorefinery where other products would be produced, it makes this process more economically viable. Obtaining biogas by anaerobic decomposition of cellulose, hemicellulose, and lignin from the spent grain proved to be a difficult task in the 1990s due to the complex structure of the mentioned compounds [60]. However, recent research has shown a positive impact of thermal-chemical and/or thermal pretreatment [61,62] and has opened the door to new research. Panjičko et al. [60] investigated spent grain as a mono-substrate in two phases: anaerobic digestion and granular bioreactor, which showed great potential in biogas production.

Phenolic compounds are a broad group that has recently attracted a lot of attention due to its antioxidant properties that have a positive effect on human health. Spent grain has proven to be a good raw material for the extraction of phenolic compounds, either by extraction [63] or by new ultrasound or microwave technologies [64]. Given that the spent grain is rich in proteins, it is not surprising that research has been conducted in this field as well. Protein extraction was successful with the application of hydrothermal pretreatment $\left(60{ }^{\circ} \mathrm{C}\right)$ with the enzyme protease $[65,66]$. Yu et al. [52] extracted polyphenols with the help of ultrasound, and enzymes as a final product obtained protein hydrolyzate, where glutamic acid and proline were most prevalent.

Due to the high moisture content, and rich chemical and nutritional composition, beer trub has proven to be a suitable medium for the cultivation of microorganisms. It is also possible to produce xylitol sweetener on spent grain hydrolyzate [67], as well as the production of lactic acid, which in a short time, due to its wide application in the pharmaceutical, chemical, food, textile, and leather industries, has become the cause of extensive research. The classic way of obtaining lactic acid is by fermentation of sugars (glucose, fructose, sucrose, and lactose) and starch ( $90 \%$ of world production) [68] and chemical processes (10\% of world production) [69]. Given the low selling price, scientists have tried to find new, cheaper raw materials from which lactic acid can be obtained. One of the possibilities for lowering production costs is the use of lignocellulose and starch-rich by-products [70].

Spent grain can also be used as a carrier to immobilize yeast during fermentation and thus replace commercial carriers. It has a high ability to bind yeast ( $430 \mathrm{mg} / \mathrm{g}$ dry matter), has no negative effects on the fermentation process, and the taste of beer is easy to apply and can be regenerated by rinsing in an alkali solution [71]. Pullulan can also be isolated from the spent grain. Pullulan and its derivatives are used in the food, pharmaceutical, and electrical industries due to their ability to form fibers and films that are insoluble in oils, and do not leak oxygen. Pullulan can be obtained from the spent grain using Aureobasidium pullulans [72]. 
Due to its nutritional and functional properties, the spent grain has also found application in food technology and human nutrition. Research has been done on the use of spent grain in the bakery industry for the production of high-fiber bread. Research has also been conducted for the confectionery industry, for the production of biscuits [73].

Spent grain can be composted and used further in agriculture. However, due to the high moisture content, spent grain cannot be composted on its own, but should be combined with other biological waste [74].

\subsection{Spent Yeast}

Depending on the type of yeast we use, beers are divided into bottom-fermented beers (lager beers) and top-fermented beers (ale beers). Yeast Saccharomyces pastorianus is used for the production of bottom-fermentation, and Saccharomyces cerevisiae is used for top-fermentation. After the end of fermentation and after maturation, the yeast precipitates to the bottom of the lagering tank (colder fermentation) or emerges on the surface (warm fermentation) [1]. Although most yeast can be easily separated after settling or floating in a tank, a portion of the yeast lags and needs to be removed by centrifugation or filtration [75].

Commercial spent brewer's yeast is inactive yeast rich in proteins, minerals, vitamins, nitrogen, and enzymes. Other chemical components are shown in Table 3. To prevent enzyme inactivation, halting the fermentation process should be done under controlled conditions ( $\mathrm{T} 30-60^{\circ} \mathrm{C}$; $\mathrm{t} 12-18 \mathrm{~h}$ ) [76]. Commercial spent brewer's yeast is bitter and should not be confused with the pure brewer's yeast that can be found on the market and is produced under specific controlled conditions [77].

Table 3. General chemical composition of spent brewer's yeast according to different sources.

\begin{tabular}{ccc}
\hline Component & Value & Source \\
\hline Non-cellulose carbohydrates & $25-35 \%$ & \\
\hline Cellulose & $17-25 \%$ \\
\hline Proteins & $15-24 \%$ \\
\hline Lignin & $\quad 39,42,78]$ \\
\hline Lipids & $8-28 \%$ \\
\hline Ash & $10 \%$ \\
\hline
\end{tabular}

Although brewer's yeast can be used multiple times in the production process (four to six), it still represents a significant amount of by-products due to its rapid biomass growth and reproduction during fermentation [79]. Just like spent grains, spent brewer's yeast is most commonly utilized in animal/fish nutrition [80]. However, most often, spent brewer's yeast, as well as spent grain, is deposited in the fields or burned. It is important to note that incineration alone causes greater environmental damage than just disposal in the fields [81].

Recently, numerous studies have been conducted to get biotechnological solutions for this by-product. Spent brewer's yeast can replace 50\% of protein from fish food or can be added as a supplement (up to 30\%) without negatively affecting growth, development, or meat quality [80].

Also, spent brewer's yeast has shown great potential in human nutrition due to its high content of proteins, minerals, and vitamins. It is possible to use spent brewer's yeast to obtain concentrates and isolates that are commercially available in the form of powder, tablets, flakes, or liquid form. Commercial spent brewer's yeast in liquid form contains enzymatically degraded yeasts for easier digestion, absorption, and usability. The biggest problems occurred with protein isolation because they are rich in nucleic acids, primarily RNA. Therefore, further research is focused on the isolation of low RNA proteins [80]. Lamoolphak et al. [81] investigated the effect of thermal hydrolysis on the extraction of proteins, and amino acids from spent brewer's yeast. The study showed that with increasing 
hydrolysis temperature $\left(250^{\circ} \mathrm{C}\right)$, there was an increase in yeast degradation, which favored increased protein production $(0.16 \mathrm{mg} / \mathrm{mg}$ dry yeast). The highest proportion of amino acids $(0.063 \mathrm{mg} / \mathrm{mg}$ dry yeast) occurred at low temperatures [81]. Spent brewer's yeast is a good source of nicotinic acid, cysteine, glycine, and glutamic acid. In addition to the vitamin B complex, one of the more important metals found in brewer's yeast that affects human health is trivalent chromium [82].

Due to the mentioned nutritional properties, spent brewer's yeast has found application as a suitable medium for the growth and development of microorganisms. The applications of spent brewer's yeast in the production of microorganisms are of great economic importance due to the development of a branch of the food industry called Functional food [83]. Champagne et al. [84] investigated the growth of bacteria from the genera Lactobacillus and Pedioccocus on two different substrates: pure spent brewer's yeast extract and a combination with baker's yeast extract. Pure spent brewer's yeast extract is a better medium [84]. Since spent brewer's yeast is rich in enzymes, there is a large field for research into the further use of these enzymes [80].

Spent brewer's yeast can also be used as a raw material for the production of $\beta$-glucan, which is used in the food industry as a thickener and as an emulsifier and stabilizer due to its good viscosity and water retention properties [85]. Worrasinchai et al. [86] explored the possibility of replacing the fat in mayonnaise with $\beta$-glucan, derived from spent brewer's yeast. Studies have shown that mayonnaise with $\beta$-glucan has a lower energy value, and better stability during storage compared to the sample. However, $\beta$-glucan replacement negatively affected appearance and color by reducing the positive impression on consumers [86]. Also, spent brewer's yeast extract can be used as a flavor enhancer [79].

Extrusion technology has also enabled the use of spent brewer's yeast as an additive to energy bars (10-30\% of the total composition). Studies conducted on energy bars have shown a significant increase in the total proportion of protein, phytic acid, density, and rougher and thicker surfaces. Many studies have been conducted on the impact of brewer's yeast on human health, and also the prevention of some diseases [87].

\subsection{Spent Hops}

Dried unfertilized female hop flowers (Humulus lupulus L.) [1], are added during the cooking of wort. Hops addition in small quantities is conducted to obtain the fullness of taste, bitterness, and better stability of beer, which is possible due to antimicrobial properties of hops. Various hop preparations are used in brewing, so in addition to cones, powdered hops, pellets, extract, or isomerized extract can be used [75]. There is a large selection of hops on the market that bring with them the characteristic flavors of the beer. Brewers generally combine several types of hops to obtain the desired characteristics of beer [88]. The general chemical composition is shown in Table 4.

Table 4. Chemical composition of spent hops according to different sources.

\begin{tabular}{|c|c|c|c|}
\hline & mponent & Value & Source \\
\hline \multirow{6}{*}{ Essential oils } & Sesquiterpene hydrocarbons & $37 \%$ & \multirow{11}{*}[79,89,90]{} \\
\hline & Monoterpene hydrocarbons & $27 \%$ & \\
\hline & Non-terpene derivatives & $18 \%$ & \\
\hline & Oxygenated sesquiterpenes & $8 \%$ & \\
\hline & Oxygenated monoterpenes & $4 \%$ & \\
\hline & Not identified & $6 \%$ & \\
\hline Lipids & & $4.5 \%$ & \\
\hline Proteins & & $22-23 \%$ & \\
\hline Nitrogen free extract & & $40 \%$ & \\
\hline Ash & & $6-6.5 \%$ & \\
\hline Crude fiber & & $23-26 \%$ & \\
\hline
\end{tabular}


Spent hops are mostly separated after the wort cooking process, just before fermentation, with the separation time-varying [73]. Some authors state that hops should remain present during fermentation because the content of proteins, minerals, and fats would have a positive effect on fermentation and the vitality, and stability of the finished product. The production of $1 \mathrm{hL}$ of beer results in $0.3 \mathrm{~kg}$ of spent hops [42]. Spent hops are mainly used as fertilizer or compost. Unlike yeasts and spent grain, spent hops have not found wider application in animal nutrition due to their bitter taste [72]. Spent hops have a higher proportion of fiber than spent grain, but their energy value is $50 \%$ lower [79]. To dispose of spent hops, feed manufacturers add dry spent hops to the spent grain, but not in a percentage greater than $5 \%$ [91].

Spent hops are a rich source of essential oils, which is why it can be used as a biological insecticide [92]. Essential oils are mainly isolated by steam distillation but newer technologies such as supercritical acid $\mathrm{CO}_{2}$ extraction are also being developed [93]. Extraction with supercritical $\mathrm{CO}_{2}$ is also possible for the extraction of other components of spent hops such as proteins, sugars, and free fatty acids [94].

Research has also been conducted on the positive impact it can have on human health. Spent hop extract has a positive effect on platelet reactivity and displays an anticoagulant effect. Thanks to flavanols, hydroxycinnamic acid, proanthocyanidin oligomers, flavan-3 monomers, and flavanol glycosides inhibited ADP induces platelet aggregation up to $11 \%$ by $7.5 \mathrm{~g} / \mathrm{mL}$ or up to $23 \%$ by $15 \mathrm{~g} / \mathrm{mL}$, $p<0.05$. Besides, spent hop extract improved the anticoagulant activity of human endothelial cells, thereby significantly reducing platelet reactivity [95].

In addition, spent hops are also used for polyphenol extraction. Thirty $\%$ of the total polyphenol content comes from hops, with only $15 \%$ ending up in the final product, while the remaining $85 \%$ lag in spent hops [96].

Spent hops contain a significant amount of proteins. The reason for this is that, during the cooking of wort, proteins are denatured and precipitated, and the precipitated proteins are removed together with the spent hops, just before the fermentation process [97]. Due to the presence of $\mathrm{Ca}^{2+}$, insoluble proteins can form complexes with soluble components of hops and peptides, which affect the final chemical composition of spent hops.

\subsection{Germ/Rootlets}

Germ/rootlets form during the malting process (germination stage). Of the total amount of barley, $3-5 \%$ of germ/rootlets can be obtained $[42,98]$. They are removed during the kilning process by deculmer. The separation process is performed because the germ/rootlets can negatively affect the beer because they absorb moisture, give a bitter taste to the final beer, and add unwanted color.

The chemical composition of the germ/rootlets, shown in Table 5, can vary depending on the grain from which it is obtained, but it mostly depends on the germination conditions [99]. Germ/rootlets are a good source of protein, vitamins, minerals, polyphenols, and selenium [100].

Cereals mean the catabolization of carbohydrates to sugars and fats into free fatty acids. In the process of germination, there is an increase in the proportion of protein, vitamin B, fiber, amino acids, free fatty acids (isoleucine, leucine, methionine, and phenylalanine valine), phytosterols [101], which affect the proper digestion of germs. 
Table 5. Chemical composition of germ/rootlets after kilning.

\begin{tabular}{ccc}
\hline Component & Value & Source \\
\hline Dry matter & $91-96 \%$ \\
\hline Crude protein & $20-25 \%$ \\
\hline Carbohydrates & $46 \%$ \\
\hline Calcium & $0.19 \%$ \\
\hline Phosphorus & $0.69 \%$ \\
\hline Magnesium & $0.17 \%$ \\
\hline Potassium & [101,102] \\
\hline Sulfur & $0.17 \%$ \\
\hline Zinc & $64 \mathrm{ppm}$ \\
\hline Manganese & $36 \mathrm{ppm}$ \\
\hline Copper & $9 \mathrm{ppm}$ \\
\hline
\end{tabular}

In the past few years, germ/rootlets have become an indispensable part of the research, and human nutrition due to their high nutritional properties, and easy and fast cultivation. Germs/rootlets are rich in nutrients. Although germ/rootlets are rarely mentioned as a by-product in beer production, due to the high proportion of nitrogen [103] and other active substances, their use in further nutrition should not be neglected. They are currently used as animal feed [104] because they are cheap and highly nutritious.

Many studies have been conducted on the use of germ/rootlets in the food industry. One of the Japanese innovations is the use of partially degraded hemicellulose products extracted from plant germ fibers, in the production of foods, and beverages containing soluble dietary fiber. However, the problem arises due to the negative taste that germs carry with them. Therefore, all further research is aimed at finding technologies that will succeed in finding the application of germs/rootlets in the food industry without negatively affecting taste [103]. For this reason, Kondo at al. [103] conducted research related to the bad taste originating from germs. They associated the bad taste with the degree of crushing during the process of separating germ/rootlets from malt. The germ/rootlets were crushed in five different stages, after which the sprouts were immersed in the liquid to study the taste. The study showed that the discomfort increased with the degree of comminution; the taste was more unpleasant with the smaller the particle size of the germ/rootlets [103].

Aborus et al. [101] researched frozen dry barley rootlets (hybrid and nonhybrid). They investigated phytochemical composition, antioxidant abilities (in vitro), antihyperglycemic activities, gastrointestinal changes, and anti-inflammatory activities. Studies have shown that the hybrid had higher phytochemical content and that it had more antioxidant abilities, hyperglycemic, and anti-inflammatory effects.

\section{By-Products and Food Industry-Value Added Products}

Besides the use in animal feed, malting and brewing by-products can be used to enrich, and improve the functional properties of different food products. Considering the increasing occurrence of obesity, diabetes, cancer, and cardiovascular diseases in the modern world, functional food combined with food industry by-products has become a focus of many research groups [38,105,106].

Since malting and brewing by-products, such as spent grains, spent hops, and spent yeast, are produced all year long, they can easily be utilized for food production. Their main constituents-minerals, nitrogen, and carbon-serve as important compounds that can add nutritive value to different products. This makes them suitable for the extraction of sugars, proteins, acids, and antioxidants [38]. 
Brewer's spent grain and spent yeast can be utilized in the baking industry as a source of dietary fibers since they are rich in $\beta$-glucan. Brewer's spent grain consists of $17 \%$ of cellulose, and $28 \%$ of non-cellulose polysaccharides such as arabinoxylans and lignin. According to several research groups, brewer's spent grain contains polyphenols [107-109] that can be redirected into different food products. Brewer's spent grain can be used as a functional food in baked snacks such as breadsticks [110]. The authors reported that the addition of brewer's spent grain can negatively affect some of the baking properties. Breadsticks with the addition of brewer's spent grain were darker in color, less crispy, and showed a lower baking volume. This can be correlated with the high fiber content in BSG.

\section{Conclusions}

Beer is one of the most consumed beverages in the world, so, it is not surprising that it plays an important role in the economy. Also, breweries have been targeted by environmental organizations due to the large number and amount of by-products created during beer production, which can negatively affect the ecosystem if not disposed of safely.

The most abundant by-product is wastewater, which is mostly discharged into the sewage systems without prior treatment, thus negatively affecting the flora and fauna of rivers and lakes. In addition to wastewater, germ/rootlets from malting spent grain, spent hops, and yeast are also extremely important by-products. These by-products are available throughout the year and can be used in animal nutrition. Although the mentioned by-products can be an environmental problem, due to their high nutritional value, they are an important biotechnological raw material. In addition to treatment and safe discharge into the sewage system, water can be used as a substrate for the growth of microalga, for hydroponic plant cultivation, and the production of biogas rich in methane and hydrogen. Spent grain, spent yeast, spent hop, and germ/rootlets, due to their high content of proteins, polyphenols, vitamins, and minerals are a focus of many studies, not only considering their utilization in animal feed, but also human nutrition, food, and pharmaceutical industries.

Author Contributions: Conceptualization, A.K.; investigation, A.K.; resources, K.M.; writing-original draft preparation, A.K.; writing—review and editing, K.H., A.J., and N.Ć.; supervision, V.K. and K.H. All authors have read and agreed to the published version of the manuscript.

Funding: This research received no external funding.

Conflicts of Interest: The authors declare no conflict of interest.

\section{References}

1. Kunze, W. Technology Brewing and Malting, 5th ed.; VLB Berlin: Berlin, Germany, 2014.

2. Beer Market By Type (Strong Beer, Light Beer), Production (Macro, Micro Brewery), Category (Premium, Super premium, Normal) and Packaging (Canned, Bottled, Draught) - Global Opportunity Analysis and Industry Forecast, 2014-2020. Available online: https:/www.premiummarketinsights.com/reports-amr/beer-market (accessed on 5 July 2020).

3. Mussatto, S.I. Brewer's spent grain: A valuable feedstock for industrial applications. J. Sci. Food Agric. 2014, 94, 1264-1275. [CrossRef]

4. LIFE YEAST - Recycling brewer's spent YEAST in innovative industrial applications. Available online: https://ec.europa.eu/environment/life/project/Projects/index.cfm?fuseaction=search.dspPage\&n_ proj_id=6265\&docType $=$ pdf (accessed on 31 July 2020).

5. Gagula, G.; Mastanjević, K.; Mastanjević, K.; Krstanović, V.; Horvat, D.; Magdić, D. The influence of packaging material on volatile compounds of pale lager beer. Food Packag. Shelf Life 2020, 24, 100496. [CrossRef]

6. Simate, G.S.; Cluett, J.; Iyuke, S.L.; Musapatika, E.T.; Ndlovu, S.; Walubita, L.F.; Alvarez, A.E. The treatment of brewery wastewater for reuse: State of the art. Desalination 2011, 273, 235-247. [CrossRef]

7. Šarić, G.; Matijević, B.; Blažić, B.; Zavadlav, S.; Halambek, J. Brewery effluents-waste or raw material? In Proceedings of the 7th International Scientific and Professional Conference, "Water For All”, Osijek, Croatia, 9-10 March 2017; Habuda-Stanić, M., Šiljeg, V., Eds.; Faculty of Food Technology Osijek, Josip Juraj Strossmayer University of Osijek: Osijek, Croatia, 2018; pp. 271-284. 
8. Brewers of Europe. Beer Statistics-2016 Edition. 2016. Available online: https://brewersofeurope.org/ uploads/mycms-files/documents/publications/2016/stats_2016_web.pdf (accessed on 4 July 2020).

9. Van der Merwe, A.I.; Friend, J.F.C. Water management at a malted barley brewery. Water SA 2002, 28, 313-318. [CrossRef]

10. Rao, A.G.; Reddy, T.S.K.; Prakash, S.S.; Vanajakshi, J.; Joseph, J.; Sarma, P.N. pH regulation of alkaline wastewater with carbon dioxide: A case study of treatment of brewery wastewater in UASB reactor coupled with absorber. Bioresour. Technol. 2007, 98, 2131-2136. [CrossRef] [PubMed]

11. Mielcarek, A.; Janczukowicz, W.; Ostrowska, K.; Jóźwiak, T.; Kłodowska, I.; Rodziewicz, J.; Zieliński, M. Biodegradability evaluation of wastewaters from malt and beer production. J. Inst. Brew. 2013, 119, 242-250. [CrossRef]

12. Enitan, A.M.; Adeyemo, J.; Kumari, S.; Swalaha, F.M.; Bux, F. Characterization of Brewery Wastewater Composition. World A. Sci. Eng. Technol. Int. J. Environ. Eco. Eng. 2015, 9. [CrossRef]

13. Thiel, P.G.; du Toit, P.J. The chemical composition of a brewery waste. J. Inst. Brew. 1965, 71, 509-514. [CrossRef]

14. Best Available Techniques (BAT). Reference Document in the Food. Drink and Milk Industries, European IPPC Bureau, First Draft (January 2017). 2017. Available online: https://ec.europa.eu/jrc/en/publication/eur-scientific-and-technical-research-reports/best-availabletechniques-bat-reference-document-food-drink-and-milk-industries-industrial (accessed on 6 July 2020).

15. Schenk, P.M.; Thomas-Hall, S.R.; Stephens, E.; Marx, U.C.; Mussgnug, J.H.; Posten, C.; Kruse, O.; Hankamer, B. Second generation biofuels: High-efficiency microalgae for biodiesel production. Bioenergy Res. 2008, 1, 20-43. [CrossRef]

16. Maintinguer, S.I.; ZampolLazaro, C.; Pachiega, R.; Varesche, M.B.A.; Sequinel, R.; de Oliveira, J.E. Hydrogen bioproduction with Enterobacter sp. isolated from brewery wastewater. Int. J. Hydrog. Energy 2017, 42, 152-160. [CrossRef]

17. Knothe, G.; Krahl, J.; van Gerpen, J. The Biodiesel Handbook; AOCS Press: Champaign, IL, USA, 2005.

18. Tomas, N.G. Hidroponski uzgoj biljaka. Ph.D. Thesis, Josip Juraj Strossmayer University of Osijek. Faculty of Agrobiotechical Sciences Osijek, Osijek, Croatia, 2019.

19. Leiper, K.A.; Miedl, M. Colloidal stability of beer. In Beer: A Quality Perspective; Bamforth, C., Ed.; Academic Press: London, UK, 2009; pp. 111-161.

20. Barbosa-Pereira, L.; Bilbao, A.; Vilches, P.; Angulo, I.; Luis, J.L.; Fité, B.; Paseiro-Losada, P.; Cruz, J.M. Brewery waste as a potential source of phenolic compounds: Optimisation of the extraction process and evaluation of antioxidant and antimicrobial activities. Food Chem. 2014, 145, 191-197. [CrossRef] [PubMed]

21. Arantes, M.K.; Alves, H.J.; Sequinel, R.; da Silva, E.A. Treatment of brewery wastewater and its use for biological production of methane and hydrogen. Int. J. Hydrog. Energy 2017, 42, 26243-26256. [CrossRef]

22. Arantes, M.K.; Sequinel, R.; Alves, H.J.; Machado, B.; Fiorini, A.; da Silva, E.A. Improvement of biohydrogen production from brewery wastewater: Evaluation of inocula, support and reactor. Int. J. Hydrog. Energy 2020, 45, 5216-5226. [CrossRef]

23. Tchobanoglous, G.; Burton, F.L.; Stensel, H.D. Wastewater Engineering: Treatment, Disposal, and Reuse; McGraw-Hill: New York, NY, USA, 1991.

24. Mohan, S.V. Fermentative hydrogen production with simultaneous wastewater treatment: Influence of pretreatment and system operating conditions. J. Sci. Ind. Res. 2008, 67, 950-961.

25. Dai, H.; Yang, X.; Dong, T.; Ke, Y.; Wang, T. Engineering application of MBR process to the treatment of beer brewing wastewater. Mod. Appl. Sci. 2010, 4, 103-109. [CrossRef]

26. Rodriguez, L.; Villaseñor, J.; Fernandez, F.J. Influence of the cleaning additives on the methane production from brewery effluents. Chem. Eng. J. 2013, 215, 685-690. [CrossRef]

27. Feng, Y.; Wang, X.; Logan, B.E.; Lee, H. Brewery wastewater treatment using air-cathode microbial fuel cells. Appl. Microbiol. Biotechnol. 2008, 78, 873-880. [CrossRef]

28. Osterman-Parac, Đ.; Sutlović, A.; Đurašević, V. Physicochemical Treatment and Biosorption of Dyehouse Effluents: Water Recycling Possibility. Tekstil 2010, 59, 307-315.

29. Wu, B.; Wang, H.; Xue, X.; Li, X. Full-scale Application of an Integrated UF/RO System for Treatment and Reuse of Electroplating Wastewater. J. Water Sus. 2012, 2, 185-191.

30. Kušter, D. Uloga filtracije u proizvodnji piva. Bachelor's Thesis, Karlovac University of Applied Sciences, Karlovac, Croatia, 2016. Available online: https:/urn.nsk.hr/urn:nbn:hr:128:249898 (accessed on 11 July 2020). 
31. Braeken, L.; van der Bruggen, B.; Vandecasteele, C. Regeneration of brewery waste water using nanofiltration. Water Res. 2004, 38, 3075-3082. [CrossRef]

32. Götz, G.; Geissen, S.-U.; Ahrens, A.; Reimann, S. Adjustment of the wastewater matrix for optimization of membrane systems applied for water reuse in breweries. J. Membr. Sci. 2014, 465, 68-77. [CrossRef]

33. Cicek, N. A review of membrane bioreactors and their potential application in the treatment of agricultural wastewater. Can. Biosyst. Eng. 2003, 45, 6-37.

34. Serdarević, A. Razvoj i primjena MBR tehnologije u procesu prečišćavanja otpadnih voda/Development and application of MBR technology in the process of wastewater treatment. Vodoprivreda 2014, 46, 77-87.

35. Alvarado-lassman, A.; Rustrian, E.; Garcı-Alvarado, M.A.; Rodriguez-Jimenez, G.C.; Houbron, E. Brewery wastewater treatment using anaerobic inverse fluidized bed reactors. Biores. Technol. 2008, 99, 3009-3015. [CrossRef]

36. Chen, H.; Changa, S.; Guoa, Q.; Hong, Y.; Wu, P. Brewery wastewater treatment using an anaerobic membrane bioreactor. Biochem. Eng. J. 2016, 105, 321-331. [CrossRef]

37. Wang, H.; Qu, Y.; Li, D.; Ambuchi, J.J.; He, W.; Zhou, X.; Liu, J.; Feng, Y. Cascade degradation of organic matters in brewery wastewater using a continuous stirred microbial electrochemical reactor and analysis of microbial communities. Sci. Rep. 2016. [CrossRef]

38. Mussatto, S.I. Biotechnological potential of brewing industry by-products. In Biotechnology for Agro-Industrial Residues Utilisation; Springer: Dordrecht, The Netherlands, 2009; pp. 313-326.

39. Robertson, J.A.; I'Anson, K.J.A.; Treimo, J.; Faulds, C.B.; Brocklehurst, T.F.; Eijsink, V.G.H.; Waldron, K.W. Profiling brewers' spent grain for composition and microbial ecology at the site of production. LWT-Food Sci. Technol. 2010, 43, 890-896. [CrossRef]

40. Andrew, J.J.; Parker, M.L.; Faulks, R.; Husband, F.; Wilde, P.; Smith, A.C.; Faulds, C.B.; Waldron, K.W. A systematic micro-dissection of brewers' spent grain. J. Cereal Sci. 2008, 47, 357-364.

41. Mccarthy, A.L.; O'Callaghan, Y.O.; Piggott, C.O.; FitzGerald, R.J.; O’Brien, N.M. Brewers' spent grain; bioactivity of phenolic component, its role in animal nutrition and potential for incorporation in functional foods: A review. Proc. Nutr. Soc. 2013, 72, 117-125. [CrossRef]

42. Mussatto, S.I.; Dragone, G.; Roberto, I.C. Brewers' spent grain: Generation, characteristics and potential applications. J. Cereal Sci. 2006, 43, 1-14. [CrossRef]

43. Al-Hadithi, A.N.; Muhsen, A.A.; Yaser, A.A. A study on the possibility of using some organic acids as preservatives for brewer's by products. J. of Agri. Water Res. Research (Iraq) 1985, 4, 229-242.

44. Kuentzel, U.; Sonnenberg, H. Conservation of pressed brewers grain with potassium sorbate. Monatsschrift fuer Brauwiss. 1997, 50, 175-181.

45. Muthusamy, N. Chemical composition of brewers spent grain-A review. Int. J. Sci. Environ. Technol. 2014, 3, 2109-2112.

46. Xiros, C.; Christakopoulos, P. Biotechnological potential of brewers spent grain and its recent applications. Waste Biomass Valori. 2012, 3, 213-232. [CrossRef]

47. Steiner, J.; Procopio, S.; Becker, T. Brewer's spent grain: Source of value-added polysaccharides for the food industry in reference to the health claims. Eur. Food Res. Technol. 2015, 241, 303-315. [CrossRef]

48. Khidzir, N.M.; Abdullah, N.; Agamuthu, P. Brewery Spent Grain: Chemical Characteristics and Utilization as an Enzyme Substrate. Malaysian J. Sci. 2010, 29, 41-51.

49. Huige, N.J. Brewery by-products and effluents. In Handbook of Brewing, 1st ed.; Hardwick, W.A., Ed.; Marcel Dekker: New York, NY, USA, 1995; pp. 501-550.

50. Ding, C.; Li, Z.X.; Fang, B.; Yan, J.L. Fermentation of Brewers' spent grain by effective microorganisms to produce proteins feed. Adv. Mat. Res. 2012, 396-398, 1980-1983. [CrossRef]

51. Hassan, S.S.; Williams, G.A.; Jaiswal, A.K. Emerging technologies for the pretreatment of lignocellulosic biomass. Bioresour. Technol. 2018, 262, 310-318. [CrossRef]

52. Yu, D.; Sun, Y.; Wang, W.; O’Keefe, S.F.; Neilson, A.P.; Feng, H.; Wang, Z.; Huang, H. Recovery of protein hydrolysates from brewer's spent grain using enzyme and ultrasonication. Int. J. Food Sci. Tech. 2020, 55, 357-368. [CrossRef]

53. Plaza, P.E.; Gallego-Morales, L.H.; Peñuela-Vásquez, M.; Lucas, S.; García-Cubero, M.T.; Coca, M. Biobutanol production from brewer's spent grain hydrolysates by Clostridium beijerinckii. Bioresour. Technol. 2017, 244, 166-174. [CrossRef] 
54. Rojas-Chamorro, J.A.; Cara, C.; Romero, I.; Ruiz, E.; Romero-García, H.M.; Mussatto, S.I.; Castro, E. Ethanol production from brewers' spent grain pretreated by dilute phosphoric acid. Energy Fuels 2018, 32, 5226-5233. [CrossRef]

55. Wilkinson, S.; Smart, K.A.; James, S.; Cook, D.J. Bioethanol production from brewers spent grains using a fungal consolidated bioprocessing (CBP) approach. Bioenergy Res. 2017, 10, 146-157. [CrossRef] [PubMed]

56. Rojas-Chamorro, J.A.; Romero, I.; López-Linares, J.C.; Castro, E. Brewer's spent grain as a source of renewable fuel through optimized dilute acid pretreatment. Renew. Energy 2020, 148, 81-90. [CrossRef]

57. White, J.S.; Yohannan, B.K.; Walker, G.M. Bioconversion of brewer's spent grains to bioethanol. FEMS Yeast Res. 2008, 8, 1175-1184. [CrossRef]

58. Xiros, C.; Topakas, E.; Katapodis, P.; Christakopoulos, P. Evaluation of Fusarium oxysporum as an enzyme factory for the hydrolysis of brewer's spent grain with improved biodegradability for ethanol production. Ind. Crops. Prod. 2008, 28, 213-224. [CrossRef]

59. González-García, S.; Morales, P.C.; Gullón, B. Estimating the environmental impacts of a brewery waste-based biorefinery: Bio-ethanol and xylooligosaccharides joint production case study. Ind. Crops. Prod. 2018, 123, 331-340. [CrossRef]

60. Panjičko, M.; Zupančič, G.D.; Fanedl, L.J.; Marinšek Logar, R.; Tišma, M.; Zelic, B. Biogas production from brewery spent grain as a mono-substrate in a two-stage process composed of solid-state anaerobic digestion and granular biomass reactors. J. Clean. Prod. 2017, 166, 519-529. [CrossRef]

61. Panjičko, M.; Zupančič, G.D.; Zelić, B. Anaerobic biodegradation of raw and pre-treated brewery spent grain utilizing solid state anaerobic digestion. Acta. Chim. Slov. 2015, 62, 818-827. [CrossRef]

62. Bochmann, G.; Drosg, B.; Fuchs, W. Anaerobic digestion of thermal pretreated brewers' spent grains. Environ. Prog. Sustain. Energy 2015, 34, 1092-1096. [CrossRef]

63. Socaci, S.A.; Fărcaş, A.C.; Diaconeasa, Z.M.; Vodnar, D.C.; Rusu, B.; Tofană, M. Influence of the extraction solvent on phenolic content, antioxidant, antimicrobial and antimutagenic activities of brewers' spent grain. J. Cereal Sci. 2018, 80, 180-187. [CrossRef]

64. Carciochi, R.A.; Sologubik, C.A.; Fernández, M.B.; Manrique, G.D.; D’Alessandro, L.G. Extraction of antioxidant phenolic compounds from brewer's spent grain: Optimization and kinetics modeling. Antioxidants 2018, 7, 45. [CrossRef] [PubMed]

65. Rommi, K.; Niemi, P.; Kemppainen, K.; Kruus, K. Impact of thermochemical pre-treatment and carbohydrate and protein hydrolyzing enzyme treatment on fractionation of protein and lignin from brewer's spent grain. J. Cereal Sci. 2018, 79, 168-173. [CrossRef]

66. Qin, F.; Johansen, A.Z.; Mussatto, S.I. Evaluation of different pretreatment strategies for protein extraction from brewer's spent grains. Ind. Crops Prod. 2018, 125, 443-453. [CrossRef]

67. Carvalheiro, F.; Duarte, L.C.; Medeiros, R.; Gírio, F.M. Xylitol production by Debaryomyces hansenii in brewery spent grain dilute-acid hydrolysate: Effect of supplementation. Biotechnol. Lett. 2007, 29, 1887-1891. [CrossRef] [PubMed]

68. Mussatto, S.I.; Fernandes, M.; Mancilha, I.M.; Roberto, I.C. Effects of medium supplementation and pH control on lactic acid production from brewer's spent grain. Biochem. Eng. J. 2008, 40, 437-444. [CrossRef]

69. Datta, R.; Henry, M. Lactic acid: Recent advances in products, processes and technologies-A review. J. Chem. Technol. Biotechnol. 2006, 81, 1119-1129. [CrossRef]

70. Balakrishnan, R.; Rajaram, S.K.; Sivaprakasam, S. Biovalorization potential of agro-forestry/industry biomass for optically pure lactic acid fermentation: Opportunities and challenges. In Biovalorisation of Wastes to Renewable Chemicals and Biofuels; Rathinam, N.K., Sani, R.K., Eds.; Elsevier: Cambridge, MA, USA, 2020; pp. 261-276.

71. Brányik, T.; Vicente, A.A.; Cruz, J.M.M.; Teixeira, J.A. Spent grains-a new support for brewing yeast immobilisation. Biotechnol. Lett. 2001, 23, 1073-1078. [CrossRef]

72. O'Rourke, T. Mash separation. Brewer's Guardian 1999, 7, 48-50.

73. Kerby, C.; Vriesekoop, F. An overview of the utilisation of brewery by-products as generated by british craft breweries. Beverages 2017, 3, 24. [CrossRef]

74. Stocks, C.; Barker, A.J.; Guy, S. The composting of brewery sludge. J. Inst. Brew. 2002, 108, 452-458. [CrossRef]

75. Lewis, M.J.; Young, T.W. Brewing; Chapman and Hall: London, UK, 1995.

76. Belousova, N.I.; Gordienko, S.V.; Eroshin, V.K. Influence of autolysis conditions on the properties of amino-acid mixtures produced by ethanol-assimilating yeast. Appl. Biochem. 1995, 31, 391-395. 
77. Bekatorou, A.; Psarianos, C.; Koutinas, A.A. Production of food grade yeasts. Food Technol. Biotech. 2006, 44, 407-415.

78. Santos, M.; Jiménez, J.J.; Bartolomé, B.; Gómez-Cordovés, C.; del Nozal, M.J. Variability of brewer's spent grain within a brewery. Food Chem. 2003, 80, 17-21. [CrossRef]

79. Huige, N.J. Brewery by-products and effluents. In Handbook of Brewing; Stewart, G.G., Priest, F.G., Eds.; CRC Press: Boca Raton, FL, USA, 2006; pp. 670-729.

80. Ferreira, I.M.P.L.V.O.; Pinhoa, O.; Vieiraa, E.; Tavarelaa, J.G. Brewer's Saccharomyces yeast biomass: Characteristics and potential applications. Trends Food Sci. Technol. 2010, 21, 77-84. [CrossRef]

81. Lamoolphak, W.; Goto, M.; Sasaki, M.; Suphantharika, M.; Muangnapoh, C.; Prommuag, C.; Shotipruk, A. Hydrothermal decomposition of yeast cells for production of proteins and amino acids. J. Hazard. Mater. 2006, 137, 1643-1648. [CrossRef]

82. Ding, W.J.; Qian, Q.F.; Hou, X.L.; Feng, W.Y.; Chai, Z.F. Determination of chromium combined with DNA, RNA and proteins in chromium-rich brewer's yeast by NAA. J. Radioanal. Nucl. Chem. 2000, 244, 259-262. [CrossRef]

83. Rakin, M.; Baras, J.; Vukasinovic, M. The influence of brewer's yeast autolysate and lactic acid bacteria on the production of a functional food additive based on beetroot juice fermentation. Food Technol. Biotech. 2004, 42, 109-113.

84. Champagne, C.P.; Gaudreau, H.; Conway, J. Effect of the production or use of mixtures of bakers or brewers' yeast extracts on their ability to promote growth of Lactobacilli and Pediococci. Electron. J. Biotechn. 2003, 6, 185-197. [CrossRef]

85. Thammakiti, S.; Suphantharika, M.; Phaesuwan, T.; Verduyn, C. Preparation of spent brewer's yeast $\beta$-glucans for potential applications in the food industry. Int. J. Food Sci. Tech. 2004, 39, 21-29. [CrossRef]

86. Worrasinchai, S.; Suphantharika, M.; Pinjai, S.; Jamnong, P. b-Glucan prepared from spent brewer's yeast as a fat replacer in mayonnaise. Food Hydrocoll. 2006, 20, 68-78. [CrossRef]

87. Stojceska, V.; Ainsworth, P.; Plunkett, A.; Ibanoglu, S. The recycling of brewer's processing by-product into ready-to-eat snacks using extrusion technology. J. Cereal Sci. 2008, 47, 469-479. [CrossRef]

88. Eyres, G.; Dufour, J.P. Hop essential oil: Analysis, chemical composition and odor characteristics. In Beer in Health and Disease Prevention, 1st ed.; Preedy, V., Ed.; Academic Press: Oxford, UK, 2009; pp. 239-254.

89. Hardwick, W.A. Handbook of Brewing; Marcel Decker: New York, NY, USA, 1995.

90. Briggs, D.E.; Hough, J.S.; Stevens, R.; Young, T.W. Malt. Brew. Sci: Hopped Wort. Beer, 2nd ed.; Chapman and Hall: New York, NY, USA, 1982.

91. Oosterveld, A.; Voragen, A.G.J.; Schols, H.A. Characterization of hop pectins shows the presence of an arabinogalactan-protein. Carbo. Poly. 2002, 49, 407-413. [CrossRef]

92. Bedini, S.; Flamini, G.; Girardi, J.; Cosci, F.; Conti, B. Not just for beer: Evaluation of spent hops (Humulus lupulus L.) as a source of eco-friendly repellents for insect pests of stored foods. J. Pest. Sci. 2015, 88, 583-592. [CrossRef]

93. Anioł, M.; Huszcza, E.; Bartmańska, A.; Żołnierczyk, A.; Mączka, W.; Wawrzeńczyk, C. Trace analysis of hop essential oils in spent hop. J. Am. Soc. Brew. Chem. 2007, 65, 214-218. [CrossRef]

94. Daenicke, R.; Rohr, K.; Engling, F.P. Influence of brewers' spent hops silage in diets for dairy cows on digestion and performance variables. In Umweltaspekte der Tierproduktion, Vorträge zum Generalthema des 103. VDLUFA-Kongresses, Ulm, Deutschland, 16th-21st September 1991; Helmut, Z., Ed.; VDLUFA-Verlag: Speyer, Germany, 1991; pp. 539-544.

95. Luzak, B.; Golanski, J.; Przygodzki, T.; Boncler, M.; Sosnowska, D.; Oszmianski, J.; Watala, C.; Rozalski, M. Extract from spent hop (Humulus lupulus L.) reduces blood platelet aggregation and improves anticoagulant activity of human endothelial cells in vitro. J. Funct. Foods 2016, 22, 257-269. [CrossRef]

96. Callemien, D.; Collin, S. Involvement of flavanoids in beer color instability during storage. J. Agric. Food Chem. 2007, 55, 9066-9073. [CrossRef]

97. Dos Santos Mathias, T.R.; Alexandre, V.M.F.; Cammarota, M.C.; de Mello, P.P.M.; Sérvulo, E.F.C. Characterization and determination of brewer'ssolid wastes composition. J. Instit. Brew. 2015, 121, 400-404. [CrossRef]

98. Ishiwaki, N.; Murayama, H.; Awayama, H.; Kanauchi, O.; Sato, T. Development of high value uses of spent grain by fractionation technology. Tech. Q. Master Brew. Assoc. Am. 2000, 37, 261-265. 
99. Donkor, O.N.; Stojanovska, L.; Ginn, P.; Ashton, J.; Vasiljevic, T. Germinated grains-Sources of bioactive compounds. Food Chem. 2012, 135, 950-959. [CrossRef]

100. Paśko, P.; Bartoń, H.; Zagrodzki, P.; Gorinstein, S.; Fołta, M.; Zachwieja, Z. Anthocyanins, total polyphenols and antioxidant activity in amaranth and quinoa seeds and sprouts during their growth. Food Chem. 2009, 115, 994-998. [CrossRef]

101. Aborus, N.E.; Čanadanović-Brunet, J.; Ćetković, G.; Šaponjac, V.T.; Vulić, J.; Ilić, N. Powdered barley sprouts: Composition, functionality and polyphenol digestibility. Int. J. Food Sci. Technol. 2017, 52, 231-238. [CrossRef]

102. Creasy, M.E.; Gunter, S.A.; Beck, P.A.; Weyers, J.S. Malt Sprouts as a Supplement for Forage Fed Beef Cattle. J. App. Anim. Res. 2001, 20, 129-140. [CrossRef]

103. Kondo, K.; Nagao, K.; Yokoo, Y. Process for producing food and beverage products from malt sprouts. Available online: https://patents.justia.com/patent/9326542 (accessed on 10 July 2020).

104. Mastanjević, K.; Krstanović, V.; Mastanjević, K.; Šarkanj, B. Malting and Brewing Industries Encounter Fusarium spp. Related Problems. Fermentation 2018, 4, 3. [CrossRef]

105. Jozinović, A.; Šubarić, D.; Ačkar, Đ.; Miličević, B.; Babić, J.; Jašić, M.; Lendić, V.K. Food industry by-products as raw materials in functional food production. Hrana u Zdravlju i Bolesti 2014, 3, 22-30.

106. Obradović, V.; Babić, J.; Šubarić, D.; Ačkar, Đ.; Jozinović, A. Improvement of nutritional and functional properties of extruded food products. J. Food Nutr. Res. 2014, 53, 189-206.

107. Meneses, N.G.T.; Martins, S.; Teixeira, J.A.; Mussatto, S.I. Influence of extraction solvents on the recovery of antioxidant phenolic compounds from brewer's spent grains. Sep. Purif. Technol. 2013, 108, 152-158. [CrossRef]

108. Moreira, M.M.; Morais, S.; Carvalho, D.O.; Barros, A.A.; Delerue-Matos, C.; Guido, L.F. Brewer's spent grain from different types of malt: Evaluation of the antioxidant activity and identification of the major phenolic compounds. Food Res. Int. 2013, 54, 382-388. [CrossRef]

109. McCarthy, A.L.; O'Callaghan, C.; Connolly, A.; Piggott, C.O.; FitzGerald, R.J.; O'Brien, N.M. Phenolic extracts of brewers' spent grain (BSG) as functional ingredients-Assessment of their DNA protective effect against oxidant-induced DNA single strand breaks in U937 cells. Food Chem. 2012, 134, 641-646. [CrossRef]

110. Ktenioudaki, A.; Chaurin, V.; Reis, S.; Gallagher, E. Brewer's spent grain as a functional ingredient for breadsticks. Int. J. Food Sci. Technol. 2012, 47, 1765-1771. [CrossRef] 